\title{
Determinants of Non-performing Assets of Commercial Banks in India: An Econometric Study
}

\author{
T.K. Jayaraman, \\ Adjunct Professor, Amrita Business School, Benglauru, Karnataka, India \\ E-mail: tkjayaraman@yahoo.com \\ Keshmeer Makun \\ Assistant Professor, School of Economics, Banking and Finance, \\ Fiji National University, Nasinu Campus, Fiji. \\ Ajeshni Sharma \\ Lecturer in Banking, School of Economics, Banking and Finance, \\ Fiji National University, Nasinu Campus, Fiji.
}

\begin{abstract}
Gross non-performing assets (NPA) as a proportion of gross assets of India's commercial banks in the public and private sectors as well in banks owned by foreign interests have been rising for the past few years. Gross NPAs of all commercial banks, as a proportion of total assets are $10.8 \%$, as of March 2018. In the case of the public sector banks, which dominate the banking sector with a share of $70 \%$ of business, the gross NPA as percent of total assets is $14.5 \%$. This paper is an empirical study focuses on causal factors, which are macroeconomic as well as bank specific that influences NPA. We employ the Autoregressive Distributed Lag (ARDL) procedure and conduct Bounds F- Tests, by using sixty quarterly observations (fiscal years 1999-2000 to 2015-16) to explore the effects of these determinants. The study findings reveal that real GDP, gross advances, total expenditures and price level are important determinants of NPA in India's commercial banks.
\end{abstract}

Key words: Non-performing assets, macroeconomics determinants, banking sector, India.

\section{INTRODUCTION}

India's financial sector with numerous institutions is relatively a more sophisticated one amongst the developing countries (Mohan and Ray, 2017). Amongst the various institutions, the commercial banks are major players in mobilizing savings of the country and providing credit to investors and households. Bank credit in India as a proportion of gross domestic product (GDP) increased from 27.8\% in 2000 to $52.6 \%$ in 2015 (World Bank, 2016). As a result, private sector investment in 2015 as a ratio of GDP rose from 24.3\% of GDP in 2000 to 33.3\% (World Bank, 2016). However, one cannot afford to ignore the negative aspects of rise in credit growth. If loan appraisal procedures tend to become weak, as banks become more aggressive to increase their respective shares of business, and if loan recovery becomes slack with rising bad loans, eventual bank failures would impose heavy costs on the economy. Bank failures in India are not uncommon.

The commercial banks non-performing assets (NPAs) as proportion of total assets, which have been growing for past three years, reached 9.6\% in Fiscal Year (FY) 2015-16 from 5\% a year earlier (IMF, 2017a). The public sector banks (PSB) which dominate the banking scene to the extent of $70 \%$ in terms of share of business, have more than $80 \%$ of NPA of the entire banking system. The NPAs of PSB according to the Economic Survey for 2016-17 (Government of India, 2017) stood at a record level of $12 \%$ as of January 2017. This is officially acknowledged to be higher than in any emerging market and with the sole exception of Russia in the developed world (Government of India, 2017).

There are various estimates of NPA depending on types of measurement. An Asset quality review (AQR) carried out by the banks in response to RBI directive in late 2014-15, bad loans are referred to as stressed assets (defined as a sum of gross NPA, re-structured assets and written off accounts) which were estimated to be in the range of $17.7 \%$ of gross advances in 2016 (Mohan and Ray, 2017). Regardless of different procedures of measurement, poor performance of banks has been causing concerns since late 2016. In this context, a study on the causal factors behind bad loans becomes important not only for the bank managements but also for the central bank, which is the entrusted with the responsibility of maintaining financial stability. The causal factors are divided into two broad categories: (i) macroeconomic determinants, which affect all banks without any distinction; and (ii) bank specific factors, which affect different banks differently. 
The objective of this paper is to identify potential determinants and investigate their effect on NPAs in India over the period of FY 1999 -2000 to 2014-15 leaving out the FY 2015-16, as it is considered as an outlier due to re-classification efforts. The paper is organized along the following lines. Section II gives trends in India's NPAs during 16 years (FY 1999-2000 to 2014-15). Section III is a brief literature survey on NPAs and its determinants. Section IV deals with the sources of the data series utilized and outlines the model and methodology employed. Section V reports the empirical results and the final Section VI presents conclusions with policy implications.

\section{TRENDS IN INDIA'S NPAs}

India's financial sector, as of 2017, comprises 93 scheduled banks of which 27 and 21 are in the public and private sectors; and the rest owned by foreign interests. The other financial sector institutions include cooperative societies, regional rural banks, post office banks, insurance companies and stock markets (Mohan and Ray, 2017). The growth impact of the commercial banks during the 16-year period of study is well reflected in rapid rise in deposits and credit disbursed. Their deposits increased from $41.3 \%$ in $1999-2000$ to $69.5 \%$ of GDP in 2014-15; whereas their advances grew from 24.9\% of GDP in 1999-2000 to 51.8\% of GDP. As of 2015, PSBs aggregate deposits were around $47.9 \%$ of GDP, with a $72.9 \%$ of market share. The PSBs disbursed credit (36.3\% of GDP) with $71.6 \%$ of market share. The private sector banks' aggregate deposits were $12.9 \%$ of GDP controlling $19.7 \%$ of market share and holding total credit about $10.6 \%$ of GDP with $20.8 \%$ of market share, foreign banks deposits $2.9 \%$ of GDP with market share of $4.4 \%$, together with total credit outstanding at $2.5 \%$ of GDP, which amounted to $4.9 \%$ of market share.

As the quality of assets was seen to be weakening with the emergence of rising ratio of gross NPA to gross advances since 2013-14, RBI applied rigorous assessment standards. The newly introduced Asset Quality Review (AQR) in mid 2015 revealed that the system wide gross NPA ratio went up from 5.1\% in September 2015 to $7.6 \%$ in March 2016 (IMF, 2017a).

\section{A BRIEF LITERATURE SURVEY}

The literature on NPAs is of recent origin, as the interest in the topic was triggered by studies on banking and financial crises in United States of America during the late 1970s, in Latin America (the early 1980s) and in East Asia (the mid1990s), in the Sub-Saharan Africa (later 1990s). Once the crises are found linked to the impaired assets of the banking system, empirical studies began to mushroom since the early 1990. The theoretical base for the link between impaired assets and financial crisis, which was triggered by banking crisis (Ekanayake and Azeez (2015), lies in the delegated monitoring authority of financial intermediation (Diamond, 1984). Under this theory, as long as the role of financial intermediation is carried out in full faith and the funds are held in trust by banks, the system is not expected to fail. It is only so when greed takes over precedence over safety of depositors funds and banks are tempted to give out risky loans. If the delegated authority is abused by banks, as noted by Diamond (1984), more adverse selection would ensue; and when banks become slack in monitoring the utilization of borrowed funds, loan defaults become the order of the day.

Empirical studies divided the causal factors into two wide categories: macroeconomic factors and bank specific factors. Macroeconomic determinants include a wide range of variables impacting cash flows of businesses and households. They include economic growth, inflation, real exchange rate and investment climate affected by expectations of various economic agents. The bank specific factors include relaxation of credit standards with a desire to capture a greater share of the market. Consequently, this leads to rise in loan defaults if borrowers fail to fulfill debt servicing obligations on time. Besides, during a credit boom often associated with the expansionary phase of the economy, bank managers tend to take risks, which fall under the description of bad management.

\section{A. Macroeconomic factors}

Keeton and Morris 1987 in their investigation of more than 2000 failed commercial banks in the United States attributed the failures to the weakening macroeconomic environment. Studies undertaken by Brownbridge (1998), Salas and Suarina (2002), Rajan and Dahal (2003), Fofack (2005), Jimnez and Saurina (2006), Das and Ghosh (2007), Khemraj and Pasha (2009), Ekanayake and Aziz (2015) and Warue (2013) in different countries and mostly as panel studies, found an inverse relationship among growth in real GDP (RGDP) and NPA. Another macroeconomic factor of interest is inflation. Fofack (2005), who found a direct relationship between inflation and NPA in Sub-Saharan African countries, argued inflation was responsible for erosion of commercial banks equity over time and therefore higher credit risk, which was confirmed by Warue (2013). However, there is contrary view. That is inflation in an economy, with heavy import restrictions, would lead to high profits for business enterprises, given the fact that wages and costs of raw materials in the short run do not rise immediately; and consequently, the windfall rise in profit earnings would boost loan repayment ability faster and hence NPA would decrease. Given these mixed results, the relationship between inflation and NPA is ambiguous and hence, it is subject to empirical study. 


\section{B. Bank Specific factors}

The bank specific factors include rapid credit growth, poor bank management, and aggressive credit policies with eagerness to increase the market share. Keeton (2003) in his study confirmed a positive relationship between growth in credit and NPA, which was attributed to deliberate relaxation of lowering of credit standards, reflecting a risk taking behavior on the part of management. Failure to enforce high levels of bank efficiency and aggressiveness to enlarge share of business resulted in increasing ratios of NPA to loans (Berger and DeYoung, 1997; Kwan and Eisenbis, 1997; Misra and Dal, 2010).

Examining the connection between cost efficiency and NPA in the context of the Czech banks from 1994-2005, Podpiera amd Weill (2008) found strong evidence of bad management as a reason for rise in NPA. A study by $\mathrm{Hu}$ et al. (2006) concluded that banks with a larger credit-deposit ratio had higher NPA. Salas and Saurina (2002) also concluded by linking all the key variables and observed that rapid credit growth, bank size, capital and market power were all directly associated with rising NPA. In addition, operating expenditure has been cited as a significant factor in determining NPAs of banks. The literature indicates that total expenditure raised by a higher allocation of resources to loan recovery measures is inversely related to NPA (Altunbas et al., 2000; Fan and Shaffer, 2004 and Girardone et al., 2004).

\section{DATA, MODEL AND METHODOLOGY}

The model proposed for the empirical investigation into the causes behind India's NPA is constrained by data availability. The data series on NPA are recent origin and all of them are in terms of annual observations from 1999-2015. While the NPA data series are taken from RBI (2016), all other relevant data series are sourced from ADB (2016), World Bank (2017) and RBI (2016). As the number of annual observations is not sufficient enough, they are split into quarterly observations by resorting to cubic spline interpolation procedure to get quarterly observations. The cubic spline interpolation procedure has been hailed as a robust method of disaggregating annual data to quarterly series (Ajao, Ibrahim and Ayoola, 2012) amongst all such procedures. The interpolation techniques have been widely applied in the empirical literature, which were also found to be free from any bias in the analysis of cointegration by researchers (Smith, 1998; Baharumshah, Lau and Khalid, 2006; Tang, 2008).

\section{A. Hypotheses}

The following hypotheses are formulated on the foregoing relationship between NPA, and the likely determinants:

1) NPA and RGDP move in opposite direction: higher the growth of the economy the lower would be NPA.

2) NPA and GA are directly associated. Growth in bank loans, due to aggressive bank credit policies and poor loan appraisal leads to increase in loan defaults and hence rise in NPA.

3) NPA and inflation relationship is ambiguous. The relationship has to be empirically tested.

4) NPA and operating expenditure, including greater allocations for loan recovery are indirectly associated. Greater the total operating expenditure, the less would be NPA.

\section{B. The Model}

The model for testing the hypotheses is formulated as follows:

$\mathrm{NPA}=\mathrm{f}(\mathrm{RGDP}, \mathrm{GA}, \mathrm{TE}, \mathrm{CPI})$

Where:

NPA $=$ NPA as percent of gross advances

RGDP = real gross domestic product (index)

$\mathrm{GA}=$ gross advances in rupees in billion rupees (current prices)

$\mathrm{TE}=$ total operating expenditure (current prices)

$\mathrm{CPI}=$ consumer price index 
Table I: NPA and other Variables Employed in the Study

\begin{tabular}{|c|c|c|c|c|c|}
\hline Fiscal Year & NPA & RGDP & GA & TE & CPI \\
\hline $1999-2000$ & 12.714449 & 100 & 4751.13 & 398.5 & 52.073 \\
\hline $2000-01$ & 11.407459 & 103.841 & 5587.66 & 487.2 & 54.1609 \\
\hline $2001-02$ & 10.406075 & 108.85 & 6809.58 & 535.6 & 56.1566 \\
\hline $2002-03$ & 8.832031 & 112.991 & 7780.43 & 615.69 & 58.6231 \\
\hline $2003-04$ & 7.185159 & 121.872 & 9020.26 & 739.21 & 60.8542 \\
\hline $2004-05$ & 5.150857 & 131.528 & 11526.82 & 798.07 & 63.1467 \\
\hline $2005-06$ & 3.293652 & 143.74 & 15513.78 & 890.06 & 65.8282 \\
\hline $2006-07$ & 2.508609 & 157.057 & 20125.1 & 1010.89 & 69.8737 \\
\hline $2007-08$ & 2.245278 & 170.576 & 25078.85 & 1181.38 & 74.3246 \\
\hline $2008-09$ & 2.248923 & 177.213 & 30382.54 & 1478.39 & 80.5321 \\
\hline $2009-10$ & 2.389248 & 192.241 & 35449.65 & 1652.54 & 89.2919 \\
\hline $2010-11$ & 2.440131 & 211.964 & 40120.79 & 2019.35 & 100 \\
\hline $2011-12$ & 3.073971 & 226.035 & 46488.08 & 2296.14 & 108.858 \\
\hline $2012-13$ & 3.249478 & 238.431 & 59718.2 & 2564.26 & 118.995 \\
\hline $2013-14$ & 3.830449 & 254.025 & 68757.48 & 3111.48 & 131.975 \\
\hline $2014-15$ & 4.220883 & 272.263 & 76606 & 3470.51 & 140.75 \\
\hline
\end{tabular}

Source: ADB (2016), World Bank (2017) and Handbook of Statistics on Indian Economy (2016).

\section{B. Methodology}

The the Autoregressive Distributed Lag (ARDL) methodology was employed. The bounds testing within the ARDL context involves dynamic specification. The period lagged values of the dependent and explanatory variables are used on the right hand side of the specification. For analysis and elasticity interpretation purpose, we take log of the variables as well as to remove any probable issue of heteroscedasticity, before resorting to bound F-test for cointegration.

\section{Co-integration Analysis}

For investigating, long term cointegration, Equation (1) is re-written in an unrestricted-error correction-model (UECM) within the ARDL context with each variable being the dependent variable and tested one at a time. The UECM equations are obtained as below:

$$
\begin{aligned}
& \Delta \ln N P A_{t}=c_{0}+\alpha_{1}(\ln N P A)_{t-1}+\alpha_{2}(\ln R G D P)_{t-1}+\alpha_{3}(\ln G A)_{t-1}+\alpha_{4}(\ln T E)_{t-1}+\alpha_{5}(\ln C P I)_{t-1} \\
& \sum_{i=1}^{n} \alpha_{6} \Delta(\ln N P A)_{t-1}+\sum_{i=1}^{n} \alpha_{7} \Delta(\ln R G D P)_{t-1}+\sum_{i=1}^{n} \alpha_{8} \Delta(\ln G A)_{t-1}+\sum_{i=1}^{n} \alpha_{9} \Delta(\ln T E)_{t-1}+\sum_{i=1}^{n} \alpha_{10} \Delta(\ln C P I)_{t-1}+\varepsilon_{t}
\end{aligned}
$$

$\Delta \ln R G D P_{t}=c_{0}+\beta_{1}(\ln N P A)_{t-1}+\beta_{2}(\ln R G D P)_{t-1}+\beta_{3}(\ln G A)_{t-1}+\beta_{4}(\ln T E)_{t-1}+\beta_{5}(\ln C P I)_{t-1}$ $\sum_{i=1}^{n} \beta_{6} \Delta(\ln N P A)_{t-1}+\sum_{i=1}^{n} \beta_{7} \Delta(\ln R G D P)_{t-1}+\sum_{i=1}^{n} \beta_{8} \Delta(\ln G A)_{t-1}+\sum_{i=1}^{n} \beta_{9} \Delta(\ln T E)_{t-1}+\sum_{i=1}^{n} \alpha \beta_{10} \Delta(\ln C P I)_{t-1}+\varepsilon_{t}$

$$
\begin{aligned}
& \Delta \ln G A_{t}=c_{0}+\gamma_{1}(\ln N P A)_{t-1}+\gamma_{2}(\ln R G D P)_{t-1}+\gamma_{3}(\ln G A)_{t-1}+\gamma_{4}(\ln T E)_{t-1}+\gamma_{5}(\ln C P I)_{t-1} \\
& \sum_{i=1}^{n} \gamma_{6} \Delta(\ln N P A)_{t-1}+\sum_{i=1}^{n} \gamma_{7} \Delta(\ln R G D P)_{t-1}+\sum_{i=1}^{n} \gamma_{8} \Delta(\ln G A)_{t-1}+\sum_{i=1}^{n} \gamma_{9} \Delta(\ln T E)_{t-1}+\sum_{i=1}^{n} \gamma_{10} \Delta(\ln C P I)_{t-1}+\varepsilon_{t}
\end{aligned}
$$




$$
\begin{aligned}
& \Delta \ln T E_{t}=c_{0}+\varphi_{1}(\ln N P A)_{t-1}+\varphi_{2}(\ln R G D P)_{t-1}+\varphi_{3}(\ln G A)_{t-1}+\varphi_{4}(\ln T E)_{t-1}+\varphi_{5}(\ln C P I)_{t-1} \\
& \sum_{i=1}^{n} \varphi_{6} \Delta(\ln N P A)_{t-1}+\sum_{i=1}^{n} \varphi_{7} \Delta(\ln R G D P)_{t-1}+\sum_{i=1}^{n} \varphi_{8} \Delta(\ln G A)_{t-1}+\sum_{i=1}^{n} \varphi_{9} \Delta(\ln T E)_{t-1}+\sum_{i=1}^{n} \varphi_{10} \Delta(\ln C P I)_{t-1}+\varepsilon_{t}
\end{aligned}
$$

$$
\begin{aligned}
& \Delta \ln C P I_{t}=c_{0}+\lambda_{1}(\ln N P A)_{t-1}+\lambda_{2}(\ln R G D P)_{t-1}+\lambda_{3}(\ln G A)_{t-1}+\lambda_{4}(\ln T E)_{t-1}+\lambda_{5}(\ln C P I)_{t-1} \\
& \sum_{i=1}^{n} \lambda_{6} \Delta(\ln N P A)_{t-1}+\sum_{i=1}^{n} \lambda_{7} \Delta(\ln R G D P)_{t-1}+\sum_{i=1}^{n} \lambda_{8} \Delta(\ln G A)_{t-1}+\sum_{i=1}^{n} \lambda_{9} \Delta(\ln T E)_{t-1}+\sum_{i=1}^{n} \lambda_{10} \Delta(\ln C P)_{t-1}+\varepsilon_{t}
\end{aligned}
$$

where, $\Delta$ is the first difference operative and indicate short-term dynamics. The coefficients with a period lagged variable indicate long-term relationship.

The null hypothesis ( $H_{o}: \alpha_{1}=\alpha_{2}=\alpha_{3}=\alpha_{4}=\alpha_{5}=o$ ) is tested in opposition to the alternative hypothesis ( $H_{1}: \alpha_{1} \neq \alpha_{2} \neq \alpha_{3} \neq \alpha_{4} \neq \alpha_{5} \neq o$ ). If the null proposition of zero long-run cointegration is rejected, the presence of the long-run relationship is ensured. Similar procedure with same null and alternative hypothesis is used to evaluate the remaining equations (2) to (6).

The bounds F-statistic is checked with the lower and upper bound critical values calculated by Pesaran et al. (2001). When the estimated F-statistic is higher than upper bound critical value, then the null hypothesis is rejected can be discarded. If the F-statistic is lower than the lower bound critical value, then the null hypothesis cannot be discarded. When the F-statistic is in between the lower and upper bound critical values, then the result is not conclusive. Since the set of critical values of Pesaran et al. (2001) are suitable only for large sized samples, Narayan (2005) calculated another set of critical values for small samples. Accordingly, we employ critical values of Narayan (2005), followed by the step for arriving at long run estimates.

We thereafter proceeded to check whether there exists any Granger causality at least in one direction in the long run and examine the presence of short-run and the long-run Granger causality within the error-correctionmechanism (ECM).

\section{RESULTS AND DISCUSSION}

Although the ARDL methodology does not require testing the stationary properties, we decided to test the time series properties of data series so we could ensure the estimates of coefficients remain robust (Gujarati and Porter, 2009). The standard ADF unit-root test was employed for would-be non-stationary disquiets. The unit root test results showed that the variables in the levels had unit root excluding RGDP which was stationary with constant and time trend. Nonetheless, variables were found to be stationary in the first difference, which confirmed the appropriateness of the methodology chosen.

The results of the bounds F-tests are provided in Table II. For equation (2) with NPA as the dependent variable, the F-statistic of 5.92 was more than the critical value of 4.156 at the five percent level. This denotes that there is a long term equilibrium affiliation amongst NPA and the independent variables. Conversely, the respective Ftest figures for other equations are either below the lower band value or in between the lower and upper band value, rejecting cointegration. Thus, there is only one cointegration equation, when NPA is the dependent variable. 
Table II: Results of Bounds F- Tests

\begin{tabular}{|c|c|c|c|c|}
\hline Dependent Variable & & \multicolumn{3}{|c|}{ Calculated F Statistic } \\
\hline $\operatorname{lnNPA}$ & & \multicolumn{3}{|c|}{$5.92 * *$} \\
\hline $\operatorname{lnRGDP}$ & & \multicolumn{3}{|c|}{2.07} \\
\hline $\ln G A$ & & \multicolumn{3}{|c|}{1.67} \\
\hline $\operatorname{lnTE}$ & & \multicolumn{3}{|c|}{3.24} \\
\hline \multirow[t]{2}{*}{$\underline{\ln C P I}$} & & \multicolumn{3}{|c|}{3.20} \\
\hline & Pesaran et al. & \multicolumn{3}{|c|}{ Narayan (2005) } \\
\hline \multirow[t]{2}{*}{ Significance Level } & \multicolumn{4}{|c|}{ Critical Values } \\
\hline & Lower Band & Upper Band & Lower Band & Upper Band \\
\hline 1 percent & 3.74 & 5.06 & 4.400 & 5.664 \\
\hline 5 percent & 2.88 & 4.01 & 3.152 & 4.156 \\
\hline 10 percent & 2.45 & 3.52 & 2.622 & 3.506 \\
\hline
\end{tabular}

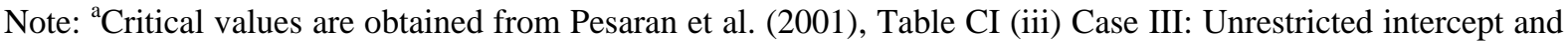
no trnd, p. 300.

${ }^{\mathrm{b} C r i t i c a l ~ v a l u e s ~ a r e ~ o b t a i n e d ~ f r o m ~ N a r a y a n ~(2005), ~ T a b l e ~ c a s e ~ I I I: ~ U n r e s t r i c t e d ~ i n t e r c e p t ~ a n d ~ n o ~ t r e n d, ~ p . ~} 10$.

** indicates significance level at 5 percent.

\section{A. Long Run Results}

Table III presents the estimated coefficients of independent variables in the cointegration equation with NPA as the dependent variable.

Table III: Long Run Results

\begin{tabular}{|cccc|}
\hline Dependent Variable is $\boldsymbol{I n N P A}$ & \\
\hline Variable & coefficient & T-Ratio & P-Value \\
\hline $\ln R G D P_{t}$ & -1.910 & -3.243 & $0.002^{*}$ \\
$\ln G A_{t}$ & 0.539 & 2.631 & $0.012^{* *}$ \\
$\ln T E_{t}$ & -0.338 & -1.723 & $0.092^{* * *}$ \\
$\ln C P I_{t}$ & 4.513 & 14.253 & $0.000^{*}$ \\
Constant & 0.081 & 0.118 & 0.906 \\
\hline Note: *, ** and *** indicate significance at one, five and ten percent points \\
\hline
\end{tabular}

The results show NPA and RGDP are indirectly associated. The estimated coefficient of RGDP, (-1.91) indicates that when the economy grows, the non-performing loans decrease. When the growth rate rises by one percent, NPA decreases by 1.91 percent. This confirms our hypothesis, that is, an increase in real GDP growth raises the incomes of businesses and households, enhances their ability to fulfill their debt financing obligations, which in turn reduces the stock of NPA.

The results show gross advance has a positive influence on NPA. The estimated coefficient advocates that a one percent point increase in gross advances raises that non-performing loan on average by 0.5 percent. Increase in loans by banks reflecting the risk taking behavior and aggressive credit policies results in higher non-performing loans. The finding is similar to that of Keeton (2003).

Furthermore, the effect of Indian banks operating expenditure is found to be mixed. While in the short term it is positively related, in the long term the total operating expenditure is inversely related with non-performing loans. The result indicates that higher total operating expenditure devoted to recovery of loans reduces the nonperforming loans in the long run.

Finally, the results also indicate strong positive relation between inflation and NPA, which is also significant, removing any ambiguity. The positive relationship indicates that increase in inflation reduces purchasing power of households and businesses and thereby decreases their ability to meet the debt obligations, contributing to the buildup of NPA. This finding is similar to that of the study by Fofack (2005). 


\section{B. Long-Run Causality}

Table IV examines the short and long-run Granger causality within the error-correction-mechanism (ECM). In regards to the equation with $\ln N P A$ as regressand, the coefficient of the error-correction-term is negative and statistically substantial at 1 percent level, indicating that the long run causality (Granger et al., 2000) is running from real GDP, gross advances, total operating expenditure and inflation to non-performing assets. However, in the remaining equations none of the error correction terms is found to be statistically significant. Therefore, we have one long term link relating real economic growth, gross advances, operating total expenditure and inflation to non-performing assets. This particular result further confirms that there is a single cointegration equation found from the bounds testing procedure. Furthermore, on the basis of F-values, there appears to be a short term underlying relationship too, running from the aforesaid four variables to non-performing assets. Thus we note both the long run and short run link to NPA from real GDP, gross advances, total operating expenditure and inflation.

Table IV: Granger Causality Tests

\begin{tabular}{|c|c|c|c|c|c|c|}
\hline Dependent Variable & \multicolumn{5}{|c|}{ F-statistics } & ECT (t-statistics) \\
\hline & $\Delta L N P A$ & $\Delta L R G D P$ & $\Delta L G A$ & $\Delta L T E$ & $\Delta L C P I$ & \\
\hline$\Delta \ln N P A$ & - & $-0.349^{* *}$ & $2.063^{*}$ & $0.061^{* *}$ & $1.831^{* * *}$ & $-0.182(-6.747)$ \\
\hline$\Delta \ln R G D P$ & 0.876 & - & $2.291^{* *}$ & 1.202 & 1.068 & $-0.019(-1.415)$ \\
\hline$\Delta \ln G A$ & 1.001 & $5.751^{*}$ & - & 6.299 & $7.192^{*}$ & $-0.033(-1.577)$ \\
\hline$\Delta \ln T E$ & 0.218 & 1.625 & $1.031^{*}$ & - & $3.815^{* *}$ & $-0.116(-0.703)$ \\
\hline$\Delta \ln C P I$ & $4.541^{* *}$ & $7.784^{*}$ & $4.871^{* *}$ & $4.417^{* *}$ & - & $-0.129(-1.641)$ \\
\hline
\end{tabular}

Note: *, ** and *** indicate significance level one, five and ten percent respectively.

\section{Short-Run Causality}

Apart from the underlying relationship running from real GDP, gross advances, total operating expenditure and inflation to non-performing assets, we also find some evidence of causality running from gross advances to real GDP, and real GDP and inflation to gross advances. There is also causality from gross advances and inflation to total operating expenditure. Equally, we find inflation is inclined in the short term by gross advances and operating expenditure, indicating bidirectional relationship between gross advances and inflation, and total expenditure and inflation respectively.

Finally, a parametric stability test was conducted along the lines of Pesaran and Pesaran (1997) by using the cumulative sum of recursive residuals (CUSUM) and the CUSUM of square (CUSUMQ) test (Brown et al., 1975) for an evaluation of coefficient constancy. Figures 1 and 2 are the plots of CUSUM and CUSUMQ statistics. The plots point to lack of variability in the coefficient as the CUSUM and CUSUMQ numbers are within the $5 \%$ critical bands of parameter constancy.

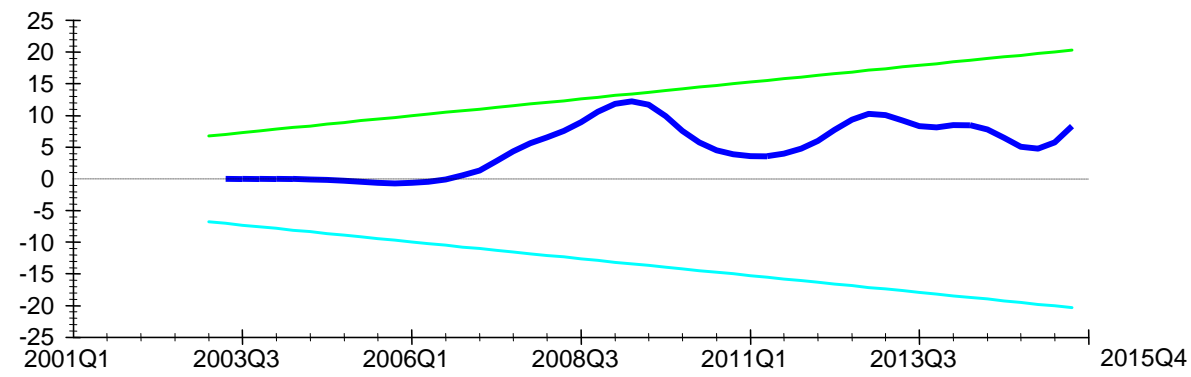

Fig 1: Plot of CUSUM test for LNPA 


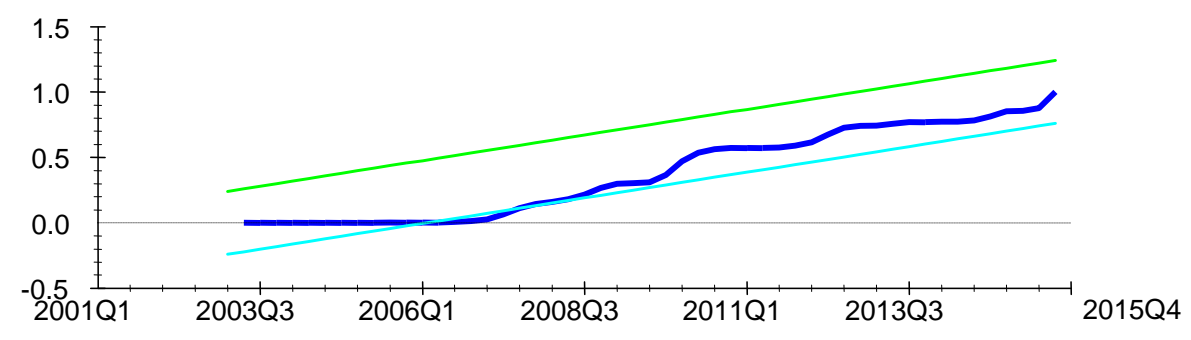

Fig 2: Plot of CUSUMQ test for LNPA

Table V reports the diagnostic tests carried out for assessing reliability of the empirical model. The Lagrange Multiplier (LM) test shows that the null proposition of no serial correlation could not be rejected. Results of Ramsey Reset and Jarque-Bera tests for model misspecification and normality revealed that the specification was right and the residuals were normally spread. Finally, the autoregressive conditional heteroscedasticity (ARCH) test shows that the errors were homoskedastic. Thus, we conclude that the ARDL model applied in the analysis was reliable.

Table V: Diagnostic Test Results

\begin{tabular}{|c|c|c|c|}
\hline Diagnostic Test & Null Hypothesis & Statistics & Decision \\
\hline $\begin{array}{c}\text { Breusch-Godfrey Serial } \\
\text { Correlation Lm test }\end{array}$ & No Serial correlation & $\mathrm{F}(1)=4.036(0.104)$ & Do not reject $\mathrm{H}_{0}$ \\
\hline Ramsey RESET test & Model is correctly specified & $\mathrm{F}(1)=0.764(0.382)$ & Do not reject $\mathrm{H}_{0}$ \\
\hline Jarque-Bera test & Normality of error term & $\mathrm{X}^{2}=1.85(0.553)$ & Do not reject $\mathrm{H}_{0}$ \\
\hline ARCH test & Homoskedasticity & $\mathrm{F}(1)=3.269(0.071)$ & Do not reject $\mathrm{H}_{0}$ \\
\hline
\end{tabular}

Note: Figures in the brackets are the probability values.

\section{CONCLUSIONS AND POLICY IMPLICATIONS}

The purpose of this paper was to empirically examine the effects of determinants of non-performing assets (NPA) of India’s commercial banks during a period of sixteen years (FY1999 to FY 2015). The findings of the study which adopted the Autoregressive Distributed Lag (ARDL) procedure, is that the macroeconomic and bank specific factors indeed influenced NPA. Economic growth was found to have an indirect relationship with NPA, confirming a rise in real GDP would boost incomes of households and cash flows of business enterprises and improve their capacity to service debt.

The findings also established the hypothesis that gross advances and NPA are directly associated. The aggressive credit policies of pushing loans result in increase in higher NPA. Furthermore, total expenditure is found to be inversely related with NPA in India. The hypothesis that rise in expenditure with additional allocation for loan recovery and better loan appraisal procedures reduces the stock of NPA. Lastly, a rise in price level as another vital macroeconomics determinant is found to be directly related to NPA. This would indicate that inflation adversely affects incomes of borrowers and reduce their ability to meet debt obligations.

Based on these findings, the policy implications are clear. First, banks in their loan appraisal procedures should pay special attention to macroeconomic forecasts made by domestic agencies, including the central bank not only in regard to servicing ability of the potential borrowers but also the stability of the banking system. Secondly, in the context of adverse impact of NPA on the economy, banks should strengthen the loan appraisal procedures and recovery measures.

\section{ACKNOWLEDGMENT}

This paper is a revised version of an earlier Working Paper which was discussed in a Faculty Seminar at Fiji National University, Nasinu Campus, Fiji, as per the standard practice. The authors thank the Seminar participants for their valuable comments. 


\section{REFERENCES}

[1] Ajao, I.O., Ibrahim, A.G. \& Ayoola, F.J. (2012). Cubic Spline Interpolation: A Robust Method of Disaggregating Annual Data to Quarterly Series. Journal of Physical Sciences and Environmental Safety, 2 (1), 1-8

[2] Asian Development Bank (2016), Key Indicators for Asia and Pacific. [Online] [Accessed: April 20, 2017]

[3] Baharumshah, A. Z., Lau, E. \& Khalid, A. M. (2006). Testing twin deficits hypothesis using VARs and variance decomposition. Journal of the Asia Pacific economy, 11(3), 331-354.

[4] Berger, A.N \& DeYoung, R. (1997). Problem loans and cost efficiency in commercial banks. Journal of Banking and Finance, 21(6), 849-870.

[5] Brownbridge, M. (1998). The causes of financial stress in local banks in Africa and implications for prudential policy. UNCTAD Discussion Papers No. 132, United Nations Conference on Trade and Development.

[6] Brown, R. L., Durbin, J., and Evans, J. M. (1975), Techniques for testing the constancy of regression relationships over time. Journal of the Royal Statistical Society, 37, 149-192.

[7] Das, A and Ghosh, S. (2007). Determinants of credit risk in Indian State-Owned banks: An empirical investigation. Economic IssuesStoke on Trent, 12(2), 27-46.

[8] Diamond, D. W. (1984). Financial intermediation and delegated monitoring. Review of Economic Studies, 51(3), 393-414.

[9] Ekanayake, E. M., \& Azeez, A. A. (2015). Determinants of Non-Performing Loans in Licensed Commercial Banks: Evidence from Sri Lanka. Asian Economic and Financial Review, 5(6), 868-882.

[10] Fofack, H. (2005). Non-performing loans in Sub-Saharan Africa: Casual analysis and macroeconomic implications. Working Paper No. 3769, World Bank Policy Research.

[11] Government of India (2017). The First Economic Survey 2016-17. [Online] http://indiabudget.gov.in/survey.asp [Accessed: April, 2017]

[12] Government of India. Reserve Bank of India Act (2008), Amended: RBI

[13] Granger, C. W. J., Huang, B. H., \& Yang, C. W. (2000). A bivariate causality between stock prices and exchange rates: evidence from recent Asian flu. The Quarterly Review of Economics and Finance, 40, 337-354.

[14] Gujarati, D. N., \& Porter, D. C. (2009). Basic Econometrics. New York, NY: McGraw-Hill/Irwin.

[15] Hu, J. L., Yang, L., Yung-Ho \& Chiu. (2006). Ownership and non-performing loans: Evidence from Taiwan’s banks. The Developing Economics, 42(3), 405-420.

[16] International Monetary Fund (IMF) (2017a): Article IV Consultation Staff Report, IMF Country Report No.17/54, Washington, D.C.: IMF

[17] International Monetary Fund (IMF) (2017b): India: Selected Issues, IMF Country Report No.17/55, Washington, D.C.: IMF

[18] Jimenez, G., Salas, V., \& Saurina, J. (2006). Credit cycles, credit risk, and prudential regulation. Banco de Espana, January.

[19] Keeton, W. R. (2003). Does faster loan growth lead to higher loan losses? Economic Review, 84(2), 57-75.

[20] Keeton, R., \& Morris, C. (1987). Why do bank loan losses differ?. Economic Review, 72(5), 3-21.

[21] Khemraj, T., \& Pasha, S. (2009). The determinants of non-performing loans: An econometric case study of Guyana. Presented at the Caribbean Centre for Banking and Finance Bi-Annual Conference on Banking and Finance, St. Augustine, Trinidad.

[22] Kwan, S. \& Eisenbis, R. (1997). Bank risk, capitalization and operating efficiency. Journal of Financial Services Research, 12(2), pp. 117-131.

[23] Misra, B. M. \& Dhal, S. (2010). Pro-cyclical management of banks' non-performing loans by the Indian public sector banks. A research publication of Bank of International Settlement: BIS.

[24] Mohan, R. \& Ray, P. (2017). Indian Financial Sector: Structure, Trends and Turns. Working Paper 17/7, International Monetary Fund (IMF).

[25] Narayan, P. K. (2005). The savings and investment nexus for China: evidence from cointegration tests. Applied Economics, 37(17), 1979-1990.

[26] Makun, K. K. (2017). Imports, remittances, direct foreign investments and economic growth in Republic of the Fiji Islands: an empirical analysis using ARDL approach. Kasetsart Journal of Social Science, https://doi.org/10.1016/j.kjss.2017.07.002

[27] Pesaran, M. H. \& Pesaran, B. (1997). Working with Microfit 4.0: Interactive Econometric Analysis. Oxford: Oxford University Press.

[28] Pesaran, M. H., Shin, Y., \& Smith, R. J. (2001). Bounds testing approaches to the analysis of level Relationships. Journal of Applied Economics, 16, 289-326.

[29] Rajan, R., \& Dhal, S. C. (2003). Non-performing loans and terms of credit of public sector banks in India: An empirical assessment, Department of Economic Analysis and Policy. Reserve Bank of India, Occasional Papers, 24(3), 81-121.

[30] Reserve Bank of India (RBI) (2015). Basic Statistical Returns of Scheduled Commercial Banks in India”, 44, March 2015 [Online], accessed in 2015

[31] RBI (2016), Report on Trends and Progress of Banking in India 2015-16, Reserve Bank of India Bulletin, March 2016.

[32] RBI (2017a) Handbook of Statistics on Indian Economy. https://rbi.org.in/scripts/AnnualPublications.aspx?head=Handbook\%20of\%20Statistics\%20on\%20Indian\%20Economy https://www.rbi.org.in/scripts/PublicationsView.aspx?id=17839 [Accessed: April, 2017]

[33] RBI (2017b), Statistical Tables of Trends. [Online] https://dbie.rbi.org.in/DBIE/dbie.rbi?site=home [Accessed: April, 2017]

[34] RBI (2017c), Strategic Debt Restructuring Scheme, Framework for Revitalizing Distressed Assets in the Economy - Guidelines on Joint Lenders' Forum (JLF) and Corrective Action Plan (CAP), RBI [Online] https://rbi.org.in/Scripts/NotificationUser.aspx?Id=9767 [Accessed: April, 2017]

[35] RBI ( 2018). Bi-Annual Financial Stability Report, March 2018, Mumbai: RBI

[36] Salas, V., \& Saurina, J. (2002). Credit risk in two institutional regimes: Spanish commercial and savings banks. Journal of Financial Services Research, 22(3), 203-224.

[37] Smith, S. F. (1998). Cointegration tests when data are linearly interpolated. Unpublished Paper, State University of New York at Albany

[38] Tang, C. F. (2008). A re-examination of the relationship between electricity consumption and economic growth in Malaysia. Energy Policy, 36(8), 3077-3085.

[39] Warue, B. N. (2013). The effects of bank specific and macroeconomic factors on non-performing loans in commercial banks in Kenya: A comparative panel data analysis. Advances in Management and Applied Economics, 6(3), 135-164.

[40] World Bank (2016). World Development Indicators, Washington, D.C. World Bank. [Online] http://data.worldbank.org/indicator/FS.AST.DOMS.GD.ZS [Accessed: December 2016]

[41] Altunbas, Y., Liu, M. H., Molyneux, P., \& Seth, R. (2000). Efficiency and Risk in Japanese Banking. Journal of Banking and Finance, 24, 1605-1628.

[42] Fan, L., Shaffer, S. (2004). Efficiency versus Risk in Large Domestic US Banks. Managerial Finance, 30, 1-19. 
[43] Girardone, C., Molyneux, P., \& Gardener, E. P. (2004). Analyzing the Determinants of Bank Efficiency: The Case of Italian Banks. Applied Economics, 36, 215-227.

[44] Podpiera, J., \& Weill, L., (2008). Bad Luck or Bad Management? Emerging Banking Market Experience. Journal of Financial Stability, 4(2), 135-148.

\section{AUTHOR PROFILE}

T.K Jayaraman is an Adjunct Professor at Amrita Business School, Bengaluru, India. He did his graduate studies for his PhD and MA degrees at the University of Hawaii, Honolulu under a Fulbright Grant and an East West Centre Grant respectively.

Keshmeer Makun is an Assistant Professor, at School of Economics, Banking and Finance, Fiji National University, Nasinu Campus, Fiji. He holds Masters of commerce in Economics from University of the South Pacific and recently finished his PhD from Northeast University of Finance \& Economics.

Ajeshni Sharma is a Lecturer in Banking, at School of Economics, Banking and Finance, Fiji National University, Nasinu Campus, Fiji. Ms. Sharma completed her Masters in Science from Glasgow Caledonian University (United Kindgom) and Undergraduate in Banking \&Finance and Information from University of the South Pacific (Fiji). 